\title{
Measured and modelled cloud condensation nuclei (CCN) concentration in São Paulo, Brazil: the importance of aerosol size-resolved chemical composition on $\mathrm{CCN}$ concentration prediction
}

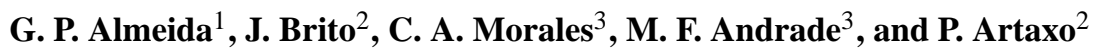 \\ ${ }^{1}$ State University of Ceará, Physics Department, Fortaleza, CE, Brazil \\ ${ }^{2}$ University of São Paulo, Physics Institute, São Paulo, SP, Brazil \\ ${ }^{3}$ University of São Paulo, Astronomy, Geophysics and Atmospheric Science Institute, São Paulo, SP, Brazil \\ Correspondence to: G. P. Almeida (gerson.almeida@uece.br)
}

Received: 19 October 2013 - Published in Atmos. Chem. Phys. Discuss.: 10 December 2013

Revised: 11 June 2014 - Accepted: 12 June 2014 - Published: 29 July 2014

\begin{abstract}
Measurements of cloud condensation nuclei $(\mathrm{CCN})$, aerosol size distribution and non-refractory chemical composition were performed from 16 to 31 October 2012 in the São Paulo Metropolitan Area (SPMA), Brazil. CCN measurements were performed at $0.23,0.45,0.68,0.90$ and $1.13 \%$ water supersaturation and were subsequently compared with the Köhler theory, considering the chemical composition. Real-time chemical composition has been obtained by deploying, for the first time in the SPMA, an aerosol chemical ionization monitor (ACSM). CCN closure analyses were performed considering internal mixtures.

Average aerosol composition during the studied period yielded (arithmetic mean \pm standard deviation) $4.81 \pm 3.05$, $3.26 \pm 2.10, \quad 0.30 \pm 0.27, \quad 0.52 \pm 0.32, \quad 0.37 \pm 0.21$ and $0.04 \pm 0.04 \mu \mathrm{g} \mathrm{m}^{-3}$ for organics, $\mathrm{BC}, \mathrm{NH}_{4}, \mathrm{SO}_{4}, \mathrm{NO}_{3}$ and $\mathrm{Cl}$, respectively. Particle number concentration was $12813 \pm 5350 \mathrm{~cm}^{-3}$, with a dominant nucleation mode. $\mathrm{CCN}$ concentrations were on average $1090 \pm 328$ and $3570 \pm 1695 \mathrm{~cm}^{-3}$ at $\mathrm{SS}=0.23 \%$ and $\mathrm{SS}=1.13 \%$, respectively.

Results show an increase in aerosol hygroscopicity in the afternoon as a result of aerosol photochemical processing, leading to an enhancement of both organic and inorganic secondary aerosols in the atmosphere, as well as an increase in aerosol average diameter.

Considering the bulk composition alone, observed $\mathrm{CCN}$ concentrations were substantially overpredicted when compared with the Köhler theory $(44.1 \pm 47.9 \%$ at $0.23 \%$ su-
\end{abstract}

persaturation and $91.4 \pm 40.3 \%$ at $1.13 \%$ supersaturation). Overall, the impact of composition on the calculated CCN concentration $\left(N_{\mathrm{CCN}}\right)$ decreases with decreasing supersaturation, partially because using bulk composition introduces less bias for large diameters and lower critical supersaturations, defined as the supersaturation at which the cloud droplet activation will take place. Results suggest that the consideration of only inorganic fraction improves the calculated $N_{\mathrm{CCN}}$.

Introducing a size-dependent chemical composition based on filter measurements from previous campaigns has considerably improved simulated values for $N_{\mathrm{CCN}}$ (average overprediction error $14.8 \pm 38.6 \%$ at $0.23 \%$ supersaturation and $3.6 \pm 21.6 \%$ at $1.13 \%$ supersaturation). This study provides the first insight on aerosol real-time composition and hygroscopicity at a site strongly impacted by emissions of a unique vehicular fleet due to the extensive biofuel usage.

\section{Introduction}

Cloud condensation nuclei $(\mathrm{CCN})$ are a subset of atmospheric aerosol that enable the condensation of water vapour and formation of cloud droplets when submitted to a given level of water vapour supersaturation. The ability of a particle to act as a CCN depends strongly on its size and chemical composition, which implies that the knowledge of both 
parameters would suffice to provide an accurate prediction on ambient $\mathrm{CCN}$ concentrations.

$\mathrm{CCN}$ are key elements of the hydrological cycle and climate on regional as well as global scales. Elevated concentrations of $\mathrm{CCN}$ tend to increase the concentration of cloud droplets in clouds and decrease their sizes, which may modify trends in rainfall (Khain, 2009, and references therein). In addition to their cloud microphysical effects, $\mathrm{CCN}$ also modulate cloud formation and convective behaviour through their radiative effects. One of the largest uncertainties in the current understanding of climate change is the response of cloud characteristics and precipitation processes to increasing aerosol concentrations. Therefore, one of the central challenges in climate assessment is to accurately describe the spatial distribution of $\mathrm{CCN}$, its relative contribution from anthropogenic activities, and the dependence of $\mathrm{CCN}$ efficiency on the aerosol size distribution and chemical composition under atmospheric conditions (e.g. McFiggans et al., 2006; IAPSAG, 2007; IPCC, 2007; Andreae and Rosenfeld, 2008).

Currently there is no consensus on how much detail on aerosol mixing state and chemical composition is needed to predict $N_{\mathrm{CCN}}$, which is expected to vary among aerosol types and with the aging of atmospheric aerosols. Nevertheless, aerosol/CCN closure has been achieved assuming a simplified composition and an internal mixture in some studies (e.g. Liu et al., 1996; Cantrell et al., 2001; Roberts et al., 2002; VanReken et al., 2003, Rissler et al., 2004; Conant et al., 2004; Gasparini et al., 2006; Broekhuizen et al., 2006; Ervens et al., 2007; Chang et al., 2007; Wang et al., 2008; Gunthe et al., 2009; Shinozuka et al., 2009), while previous studies were largely unsuccessful (Bigg, 1986; Quinn et al., 1993; Martin et al., 1994). Given the complex mixtures of aerosol composition, with both inorganic and organic components, and the composition dependency on aerosol size, a complete and rigorous description of aerosol composition, mixing state and also their ability to act a $\mathrm{CCN}$ is a difficult task. As a result, the representation of aerosol composition and mixing state in large-scale models is often greatly simplified. A common approximation, for example, is to consider aerosols to be internally mixed, i.e. particles of any size are a mixture of all participating species and have an identical composition. Nevertheless, such simplified aerosol representation on atmospheric models can be significantly improved using an efficient parameterization for the calculated $N_{\mathrm{CCN}}$ given the current measurements techniques.

Megacities and large city clusters are major source regions of atmospheric particulate matter and its precursors, with regional and global impacts (Gurjar et al., 2008). In recent years a number of studies were performed aiming to characterize the $\mathrm{CCN}$ properties of the aerosol particles in urban environments and their effects on regional air quality and climate (e.g. Matsumoto et al., 1997; Yum et al., 2005, 2007; Broekhuizen et al., 2006; Kuwata et al., 2007, 2008, 2009; Wiedensohler et al., 2009; Rose et al., 2010, 2011; Kuhn et al., 2010; Gunthe et al., 2011; Lance et al., 2013; Mei et al., 2013).

Aiming to constrain aerosol sources, processing, and its impact on climate and human health in the São Paulo Metropolitan Area (SPMA), the NUANCE-SP (Narrowing the Uncertainties in Aerosol aNd Climate changEes in the state of São Paulo) project has been designed. With 20 million people and over 7 million vehicles using a blending of gasoline with anhydrous ethanol (gasohol), pure ethanol, or diesel with biodiesel, the SPMA is one of the largest urbanized regions on the planet. Furthermore, the region is often impacted by industrial emissions (Albuquerque et al., 2012), thus resulting in a complex suite of sources of aerosols and its precursors. Within the scope of the NUANCE-SP project, aerosol and trace gas measurements were performed during winter and spring of 2012 within the city of São Paulo.

In this study we report the first $\mathrm{CCN}$ measurements performed within the SPMA. Furthermore, supporting measurements including real-time non-refractory chemical speciation, aerosol size distribution and black carbon (BC) concentration were performed. A comparison of modelled and observed $N_{\mathrm{CCN}}$ considering size-resolved chemical composition based on filter measurements from previous campaigns has been performed as well.

\section{Experimental}

\subsection{Measuring site and meteorological conditions}

The SPMA is located at $23.5^{\circ} \mathrm{S}, 46.6^{\circ} \mathrm{W}$, in the southeastern portion of Brazil and consists of 39 highly urbanized and industrialized towns, among which is included the city of São Paulo (Sánchez-Ccoyllo and Andrade, 2002). The urban site is almost entirely located in the sedimentary basin of the Tietê River, oriented from east to west, with a mean elevation of $720 \mathrm{~m}$ above sea level on an extensive floodplain. This basin is bordered to the north by the Cantareira Hills, also oriented east to west and with altitudes reaching up to $1200 \mathrm{~m}$. The southeast side of the valley is delimited by Serra do Mar with altitudes generally exceeding $800 \mathrm{~m}$. The SPMA is approximately $45 \mathrm{~km}$ from the Atlantic Ocean, is about $0.1 \%$ of the Brazilian territory and is the fourth largest urban conglomeration in the world. The climate is subtropical with dry winters and wet summers (Oliveira et al., 2003). The measurements were made at the Armando Salles de Oliveira campus of the University of São Paulo. The campus is a vast park, with an area of $7.4 \mathrm{~km}^{2}$, without strong local sources. Thus, air masses arriving at the station should be well mixed and make the measurements representative of the ambient pollution burden of the city.

The instrumentation was set-up at the rooftop of the Pelletron particle beams accelerator building, in the Physics institute of the University of São Paulo. The top of the tower is about $40 \mathrm{~m}$ above mean ground level. Three vertical sampling 

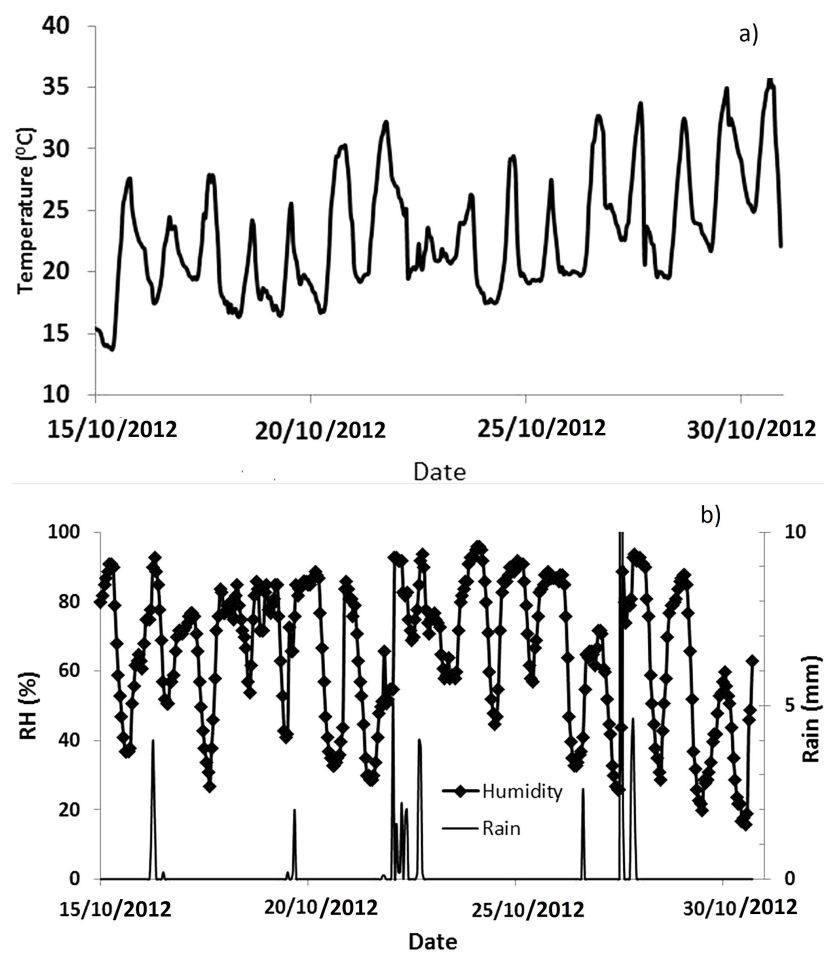

Figure 1. Time series of the (a) temperature and (b) RH and precipitation at the sampling site during the studied period.

lines with $\mathrm{PM}_{2.5}$ inlets mounted $1 \mathrm{~m}$ above the roof provided sample air to the instruments. The sampling lines to the instruments were $3 / 8$ in. stainless steel tubing with an inner diameter of $1 / 4 \mathrm{in}$. from the inlet to the instruments and $2.2 \mathrm{~m}$ in length. Each sampling line was exclusive for BC, chemical speciation, and size-distribution (as well as $\mathrm{CCN}$ ) measurements. Besides the instrumentation for aerosol characterization, a meteorological station (Lufft $\mathrm{GmbH}$, model Ventus-200A) has been deployed as well. During the study the weather was sunny with occasional precipitation. The average air temperature and relative humidity $(\mathrm{RH})$ for the whole period was $23.0^{\circ} \mathrm{C}$ and $69 \%$, varying from 13.9 to $36.0^{\circ} \mathrm{C}$ and from 96 down to $19 \%$, respectively (Fig. 1). During the period a moderate increase in the mean temperature was observed. Observations suggest low wind intensities during the period.

Although originally planned, $\mathrm{CCN}$ measurements were not carried out downstream of a differential mobility analyser (DMA) due to instrumental issues. Such set-up provides the activation fraction for a given dry aerosol diameter, allowing us to better assess the role of the chemical composition.

Data presented in this study include aerosol size distribution, $\mathrm{CCN}$ spectra, $\mathrm{BC}$ concentration and non-refractory chemical composition, measured from 16 to 31 October 2012, when we evaluated that the best combination of high quality data were available. All measurements are reported at local ambient pressure and temperature conditions. Local time (universal time coordinated (UTC) minus $3 \mathrm{~h}$ ) is used throughout this study. In the following section a description of the instrumentation used is provided.

\section{Instrumentation}

\subsection{Cloud condensation nuclei counter (CCNC)}

A single-column continuous-flow stream-wise thermal gradient CCN chamber (DMT CCNC-100; Roberts and Nenes, 2005; Lance et al., 2006) was used to measure the total polydisperse CCN number concentration as a function of time and supersaturation (SS). The effective water vapour supersaturation was regulated by the temperature gradient applied between the upper and lower wetted ends of the CCNC flow column, where the activation takes place. Only particles having lower critical supersaturation $\left(\mathrm{SS}_{\text {crit }}\right)$ than the $\mathrm{SS}$ in the column are activated and can grow into the supermicron size range. Droplets leaving the column are sized by an optical particle counter (OPC) and counted as $\mathrm{CCN}$ if their diameter is larger than a threshold size of $0.75 \mu \mathrm{m}$.

The CCNC was operated at a total flow rate of $0.5 \mathrm{~L} \mathrm{~min}^{-1}$ with a sheath-to-aerosol flow ratio of $10: 1$. One measurement cycle included measurements at five different SS $(0.20$, $0.40,0.60,0.80$, and $1.0 \%$ ). The $\mathrm{CCN}$ concentration at each SS was measured for $5 \mathrm{~min}$, and we evaluated only the data produced after complete adjustment to the supersaturation level.

For this data set, factory calibration using $\left(\mathrm{NH}_{4}\right)_{2} \mathrm{SO}_{4}$ was applied, considering recommended corrections from recent literature. Lance et al. (2006) has provided the correction function in supersaturation for a given ambient pressure. Taking in account that the system was originally calibrated in Boulder, Colorado ( 820 mbar), and deployed in São Paulo (928 mbar), the correction factor is roughly $13 \%$.

As such, the supersaturation levels measurements during our campaign were estimated as $0.23,0.45,0.68,0.90$, and $1.13 \%$.

To determine that the instrument was working correctly we considered the temperatures presented by the instrument, the variation in $\mathrm{CCN}$ concentration according to the related supersaturation, the amount of mass determined by the ACSM (aerosol chemical ionization monitor), and the DMPS (differential mobility particle sizer) aerosol spectra. In our analysis those factors were good enough to ensure the reliability on the presented data.

\subsection{Differential mobility particle sizer (DMPS) / condensation particle counter (CPC)}

A DMPS consisting of a bipolar charger, a medium-long Vienna type DMA (Winklmayr et al., 1991) with a sample flow of $1.1 \mathrm{~L} \mathrm{~min}^{-1}$ and sheath flow of $6 \mathrm{~L} \mathrm{~min}^{-1}$, and butanolbased CPC was used to measure number-size distribution of aerosol particles with diameters in the range $10-500 \mathrm{~nm}$. 
The CPC used for particle detection after the DMA was a 3010 model (TSI Inc., Shoreview, MN, USA). The CPC was calibrated for counting efficiency as a function of particle size. During the measurements, the DMA was operated in a stepwise scanning mode starting from a $10 \mathrm{~nm}$ diameter and stepped upwards or downwards, respectively. Overall, $22 \mathrm{di}-$ ameter steps were used in the scans for a total of 22 mobility channels. A single scan over the whole size range took $5 \mathrm{~min}$. A CPC (TSI 3772) was operated in parallel for comparison with particle number concentrations from the DMPS. Based on such intercomparison, DMPS data has been corrected by a factor of 1.12 to the whole campaign. Intercomparison has been performed for particle numbers below $10000 \mathrm{~cm}^{-3}$ due to decreased accuracy in the CPC. Undercounting of the DMPS may have been caused by slight deviations of the sample and sheath flow rates from the nominal values, or a DMA transfer probability lower than assumed.

\subsection{A multiangle absorption photometer (MAAP)}

Real-time BC mass concentration was measured using the MAAP (Thermo Scientific model 5012). The instrument measures simultaneously the optical attenuation and reflection of particles deposited on a glass fibrous filter from several detection angles. By assuming an absorption efficiency of $6.6 \mathrm{~m}^{2} \mathrm{~g}^{-1}$ at $637 \mathrm{~nm}$, the instrument converts light absorption to BC concentration (Petzold and Schönlinner, 2004; Müller et al., 2011).

\subsection{Aerosol chemical speciation monitor (ACSM)}

An ACSM was used to provide real-time (30 min resolution) chemically resolved mass concentrations of particulate ammonium, nitrate, sulfate, chloride, and organic species in the submicron size range (Ng et al., 2011). The ACSM efficiently samples aerosol particles through an aerodynamic lens in the $75-650 \mathrm{~nm}$ size ranges. The focused particle beam is transmitted into a detection chamber where the nonrefractory fraction flash vaporizes in a hot oven (typically above $600^{\circ} \mathrm{C}$ ). Subsequently, evaporated gas phase compounds are ionized with a $70 \mathrm{eV}$ electron impact and its spectrum obtained using a quadrupole mass spectrometer. The chemical speciation is determined via deconvolution of the mass spectra according to the work described by Allan et al. (2004).

\section{Results from observations}

\subsection{Measured aerosol and $\mathrm{CCN}$ activation properties}

The time series of CCN number concentrations measured at different supersaturations are shown in Fig. 2a. As expected, CCN concentration increases with supersaturation. The CCN hourly mean number concentrations varied between 517 and $2291 \mathrm{~cm}^{-3}$ at SS $=0.23 \%$ and between 1191
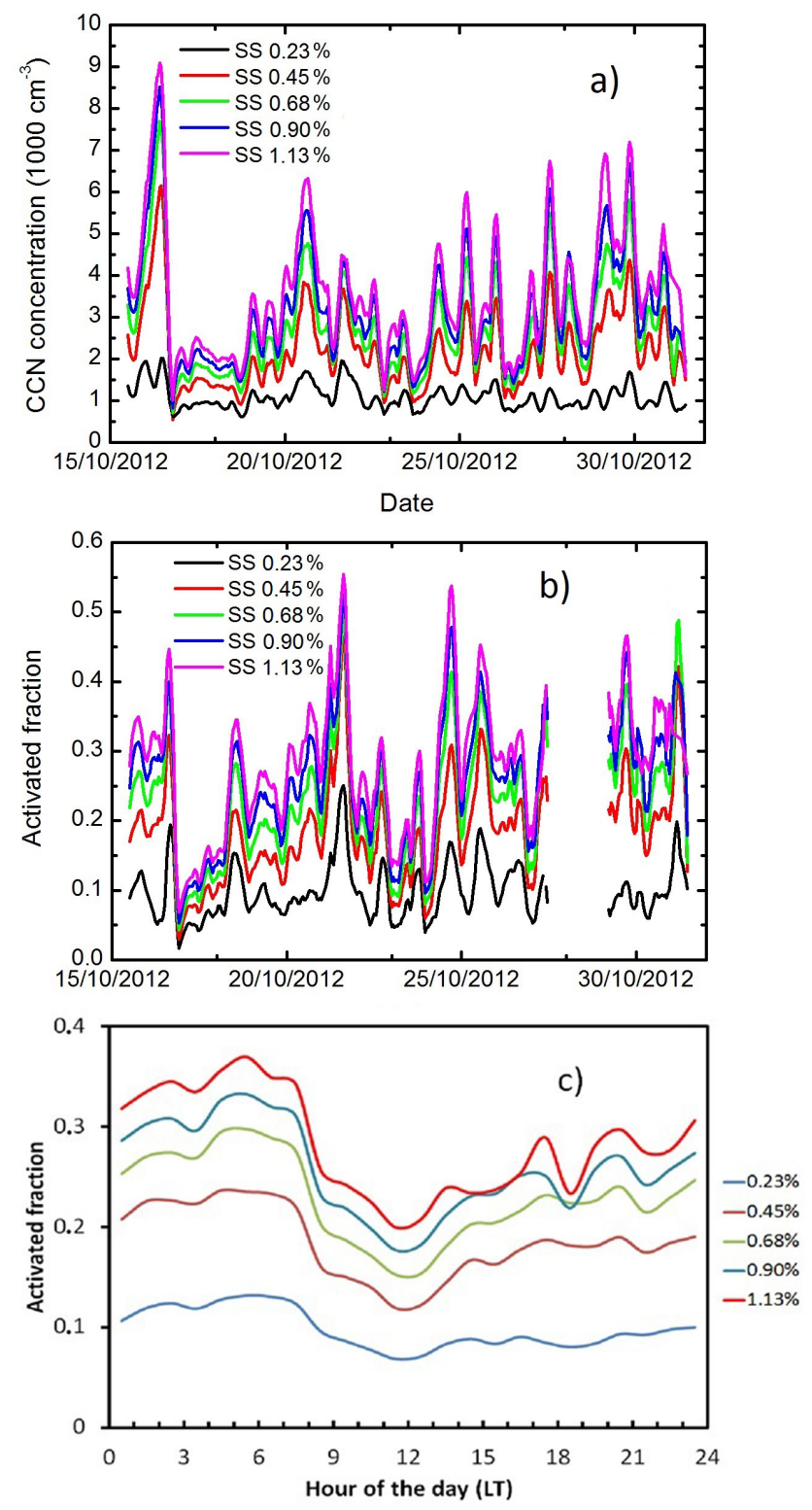

Figure 2. Time series of (a) CCN number concentration, (b) the activated fraction (\#CCN/N10-500) and (c) the mean hourly average over the whole period. The different colours represent the different SS.

and $10256 \mathrm{~cm}^{-3}$ at $\mathrm{SS}=1.13 \%$ (highest SS) with mean values and standard deviations of $1090 \pm 328 \mathrm{~cm}^{-3}$ and $3570 \pm 1695 \mathrm{~cm}^{-3}$, respectively. Minimum and maximum observed CCN number concentrations at a certain SS differed by a factor of $4-1$. The observed values are significantly lower than those observed in the megacity region of Beijing (Gunthe et al., 2011). Figure 2b shows the activated fraction, i.e. the ratio of the $\mathrm{CCN}$ number concentration relative to the integrated DMPS number concentration. One interesting feature revealed in Fig. $2 \mathrm{a}$ is the low variability of $\mathrm{CCN}$ concentration activated at $0.23 \%$. Even during the large aerosol 
Table 1. Details on the mean measured $N_{C C N}$ values furnished by CCNC for São Paulo from 16 to 31 October 2012. Supersaturation values are estimated considering the air pressure between the operating conditions in São Paulo and that during factory calibration.

\begin{tabular}{cccccc}
\hline Supersaturation & $0.23 \%$ & $0.45 \%$ & $0.68 \%$ & $0.90 \%$ & $1.13 \%$ \\
\hline Mean $N_{\mathrm{CCN}}$ & $1090 \pm 328$ & $2202 \pm 1035$ & $2776 \pm 1331$ & $3175 \pm 1503$ & $3570 \pm 1695$ \\
Activated fraction & $0.10 \pm 0.05$ & $0.19 \pm 0.09$ & $0.23 \pm 0.10$ & $0.26 \pm 0.11$ & $0.28 \pm 0.12$ \\
\hline
\end{tabular}

Table 2. Mean concentration ( \pm standard deviation) for organics, $\mathrm{NH}_{4}$, sulfate, nitrate, chloride and black carbon concentrations (in $\mu \mathrm{g} \mathrm{m}^{-3}$ ) measured in São Paulo from 16 to 31 October 2012.

\begin{tabular}{cccccc}
\hline Org & $\mathrm{NH}_{4}$ & $\mathrm{SO}_{4}$ & $\mathrm{NO}_{3}$ & $\mathrm{Cl}$ & $\mathrm{BC}$ \\
\hline $4.81 \pm 3.05$ & $0.30 \pm 0.27$ & $0.52 \pm 0.32$ & $0.37 \pm 0.21$ & $0.04 \pm 0.04$ & $3.26 \pm 2.10$ \\
\hline
\end{tabular}

concentration event on 16 October $2012, \mathrm{CCN}$ concentration does not exceed $2000 \mathrm{~cm}^{-3}$, showing an enhancement factor as high as 2. Conversely, $\mathrm{CCN}$ concentration activated at $0.45 \%$ SS increased over four times during the same event. A summary of $\mathrm{CCN}$ concentration observed during the period is shown in Table 1. Overall, the activated fraction varied by a factor of $\sim 4-6$. The mean hourly activated fraction is shown in Fig. 2c. The activated fraction strongly decreases in the morning hours, probably due to rush hour emission, consistent with observations of Lance et al. (2013). Overall, the activated fractions are under 0.4 , with mean values of $0.10 \pm 0.05$ for $\mathrm{SS}=0.23 \%$ and $0.29 \pm 0.15$ for $\mathrm{SS}=1.13 \%$. Throughout the day, the activated fraction increases, probably due to a combination of increase in average diameter as well as production of secondary organic and inorganic aerosols. Mean characteristics of the aerosol size distribution is shown in Fig. 3. The aerosol size distribution was most of the time monomodal and occasionally bimodal. Figure $3 \mathrm{a}$ depicts such a feature for the pollution event for 16 October 2012. In many occasions it is possible to see nucleation events occurring, as is observed at 7 and $9 \mathrm{~h}$, when a large number of small particles bellow $40 \mathrm{~nm}$ are observed, as a result of fresh traffic emission during morning hours. In the next few hours these particles seem to grow by condensation, the size distribution becomes more peaked and shifts to the right. On 17 October (Fig. 3b), the aerosol concentration was lower than those observed during 16 October, and the nucleation process is not evident. The temporal evolution of the mean aerosol concentration $(\mathrm{CN})$ is also marked by the appearance of several peaks that alternates with low $\mathrm{CN}$ values (Fig. 3c). Given the strong coupling between atmospheric processes, including aerosol growth and formation of secondary aerosols, a strong correlation is not observed between $\mathrm{CN}$ and $N_{\mathrm{CCN}}$ peaks throughout the sampling period.

During the whole period the integrated number concentration varied between $3000 \mathrm{~cm}^{-3}$ and $27174 \mathrm{~cm}^{-3}$, with a mean aerosol concentration of $12813 \pm 5350 \mathrm{~cm}^{-3}$ (Fig. 3c). Figure $3 \mathrm{~d}$ shows the time series of aerosol number and volume mean diameter, yielding an average value of $58 \mathrm{~nm}$ for the former and $117 \mathrm{~nm}$ for the latter. The mean aerosol number concentration attained a maximum value at noon (Fig. 3e), and decreased continuously thereafter. During observations a substantial fraction of particles were present below $\sim 40 \mathrm{~nm}$ as was measured by the DMPS. The scrutiny of the aerosol concentration data reveals that there is a lot of variation during the day as a function of meteorological condition, but the general trends shown in Fig. 3e is maintained. The second quartile approaches the mean values and the standard deviation is about the same for all hours of the day.

The bulk mass concentrations of ammonium, sulfate, nitrate and organics as measured by the ACSM, are shown in Fig. 4a, along with the BC mass concentrations measured by the MAAP. Results are shown as $1 \mathrm{~h}$ averages. Substantial variation on chemical composition was observed in the time-averaged ACSM data. The balance of ammonium, nitrate and sulfate concentrations revealed that the aerosol was far from being completely neutralized in many moments, especially during the morning, which indicate that aerosol were relatively acidic and that a considerable amount of sulfate could be in the form of ammonium bisulfate, as was also observed by Quinn et al. (2006) and Middlebrook et al. (2012). During other time intervals, the amount of $\mathrm{NH}_{4}$ was above the amount needed for complete neutralization, and sulfate was probably present as ammonium sulfate, as is shown in Fig. 4b.

Figure $4 \mathrm{c}$ shows the mass fractions of the chemical components, listed in Table 2. The most abundant observed species were organics and $\mathrm{BC}$, with a combined $86 \%$ of all mass (49.3 and $36.9 \%$ for organics and BC, respectively), indicating the relevant impact of diesel (heavy-duty) fuelled vehicles during the study period. Other species contributed with 5.6, 4.3, 3.4 and $0.4 \%$, for $\mathrm{SO}_{4}, \mathrm{NO}_{3}, \mathrm{NH}_{4}$ and $\mathrm{Cl}$, respectively. The relative contributions of $\mathrm{Cl}, \mathrm{NH}_{4}, \mathrm{NO}_{3}$ and $\mathrm{SO}_{4}$ to the total mass fraction are relatively small (less than $14 \%$ on average) but change significantly during the days (by a factor of 4) of the measurement period. Organic compounds and $\mathrm{BC}$ provide the largest contribution to the total mass 

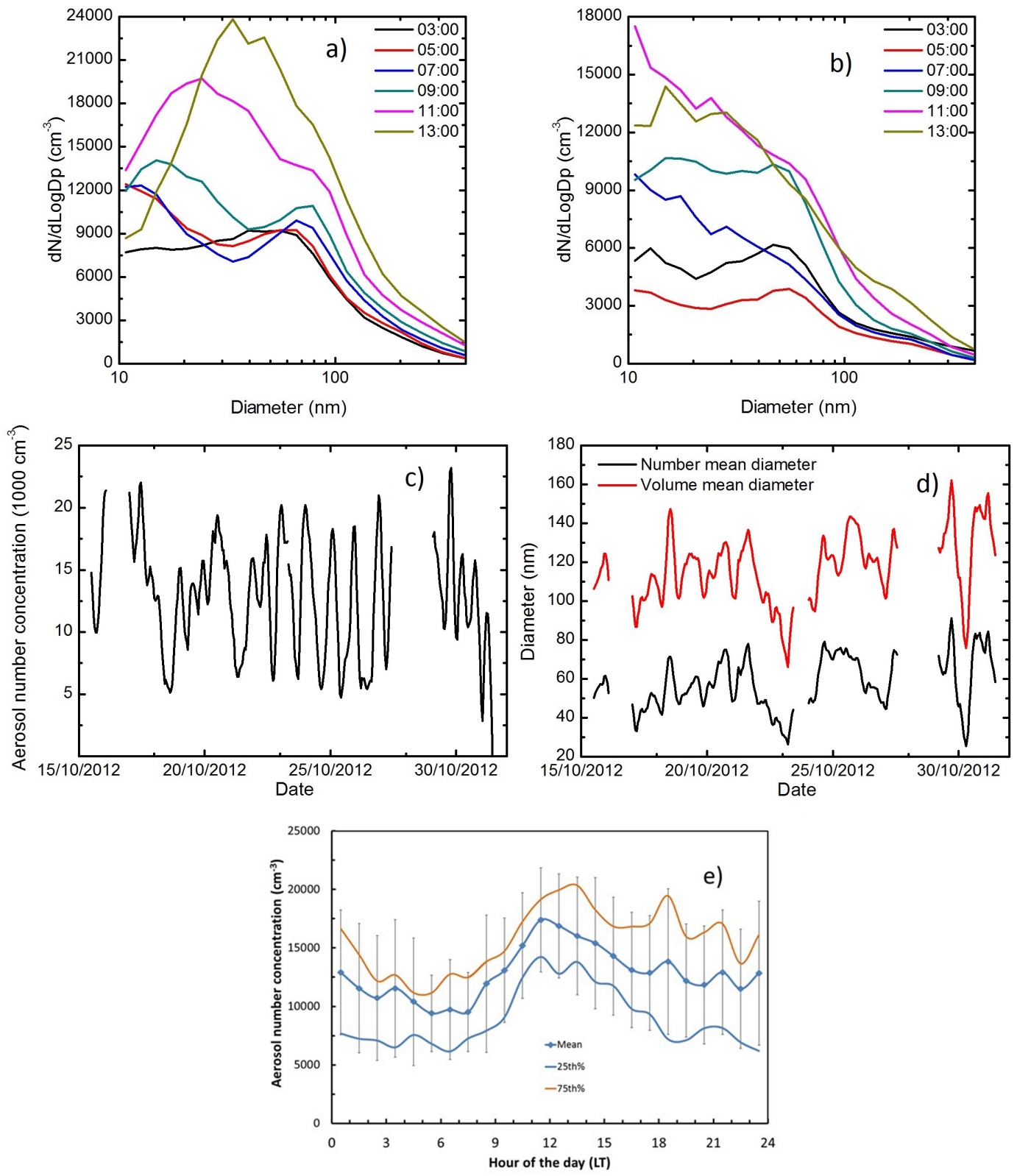

Figure 3. (a) Aerosol size distribution during 16 October 2012 in SP, (b) the same as in (a), but for 17 October. (c) Total particle concentration from 10 to $500 \mathrm{~nm}$, (d) mean particle diameter and mean particle volumetric diameter, and (e) total particle number concentration. The 25 and $75 \%$ lines refer to the first and third quartiles while bars represent standard deviation.

of aerosols, in agreement with previous studies in the area (Ynoue and Andrade, 2004). Among the identified species, $\mathrm{BC}$ exhibited the largest variability. In absolute terms, the mean hourly concentration of inorganics does not exhibit a remarkable variation during the day. $\mathrm{SO}_{4}$, for example, ranges from 0.45 to $0.65 \mu \mathrm{g} \mathrm{m}^{-3}$. Organics, however, given the much higher ambient concentration, were observed to span over a wider range of values throughout the day (from 3.5 up to $6.5 \mu \mathrm{g} \mathrm{m}^{-3}$ ). In relative terms, however, both organics and inorganics present a comparable variation during the day (45 and $30 \%$ relative to peak value, respec- tively). The minimum values are observed at 08:00 LT (local time), while the maximum values are observed at $14 \mathrm{~h}$, as is shown in Fig. 4d. The lower concentration value for the organic fraction in aerosols seems to occur $1 \mathrm{~h}$ later than that observed for the aerosol number concentration. This is probably because the traffic emission results in nucleation of aerosols in diameters lower than $40 \mathrm{~nm}$, which are not measured by the ACSM or low concentration of secondary organic aerosol. The mean concentrations observed during the whole period are $4.81 \pm 3.05,3.26 \pm 2.10,0.30 \pm 0.27$, 

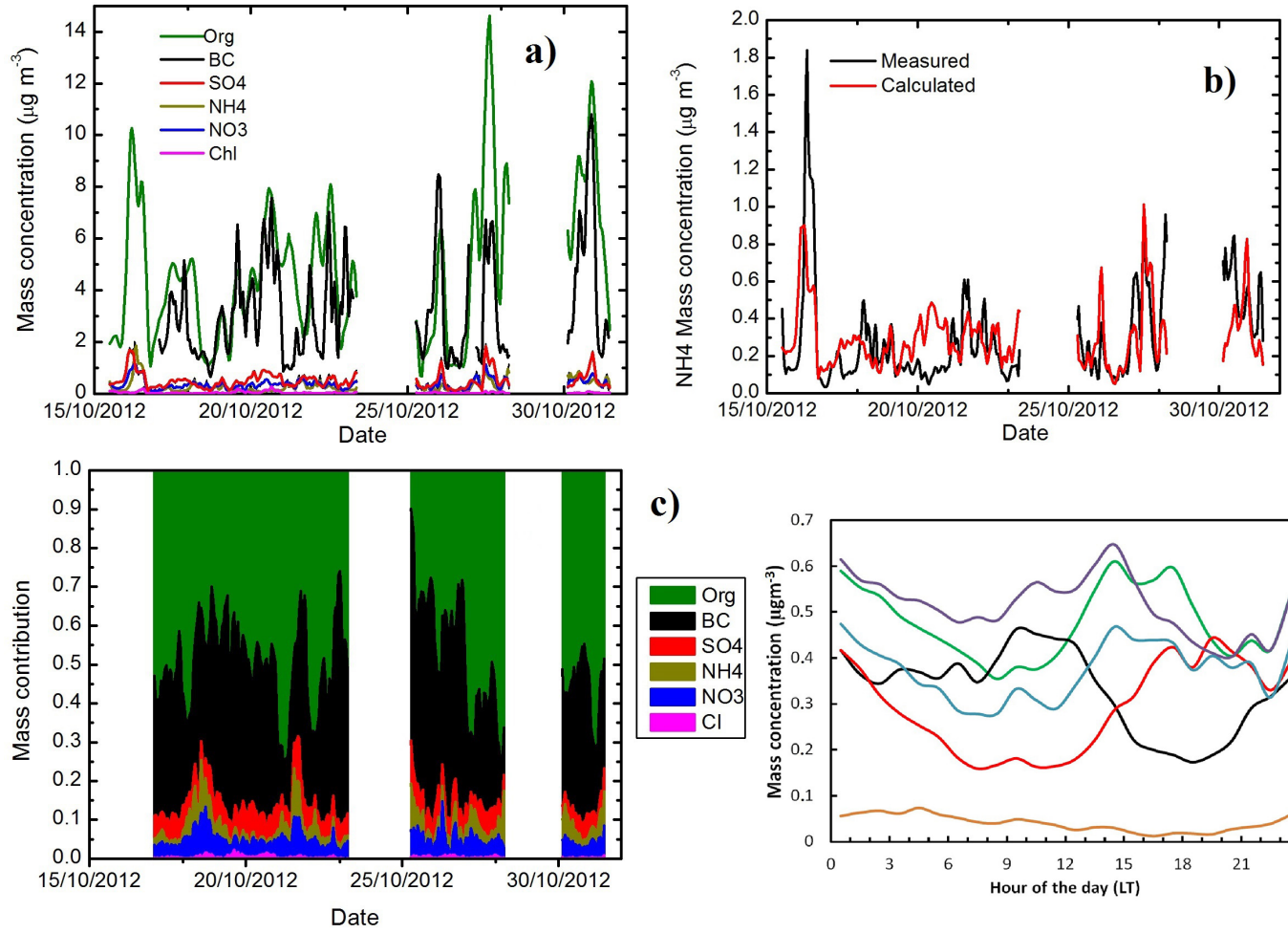

c)
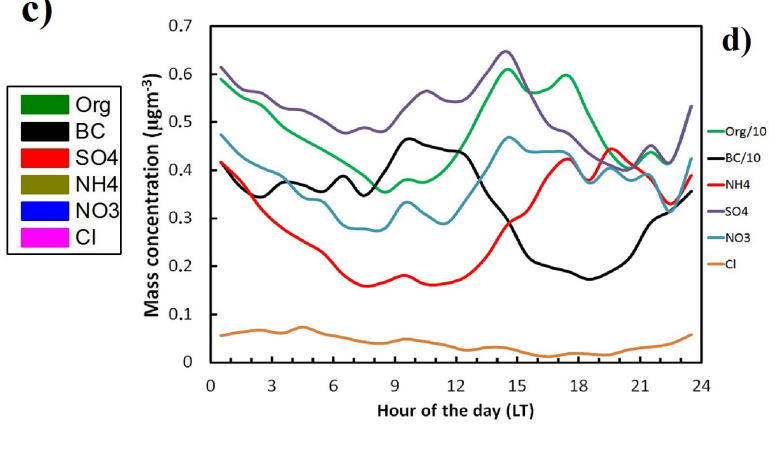

Figure 4. Chemical composition of the aerosol, measured by the ACSM and the MAAP. (a) Mass concentration of the individual species; (b) mass concentration of the measured $\mathrm{NH}_{4}$ and the calculated amount needed for complete neutralization; (c) the mass fractions of the organics, $\mathrm{NH}_{4}, \mathrm{NO}_{3}, \mathrm{SO}_{4}$ and black carbon; and (d) the mean aerosol chemical composition as a function of local time.

$0.52 \pm 0.32,0.37 \pm 0.21$ and $0.04 \pm 0.04 \mu \mathrm{g} \mathrm{m}^{-3}$ for organics, $\mathrm{BC}, \mathrm{NH}_{4}, \mathrm{SO}_{4}, \mathrm{NO}_{3}$ and $\mathrm{Cl}$, respectively.

Still considering the data from 16 and 17 October, one can observe that the activated fraction (Fig. 2b) decreases significantly when the inorganic fraction is reduced (Fig. 4a), even when the aerosol concentration remains relatively large (Fig. 3c). Data analysis also indicates that the CCN concentration is much better correlated to the inorganic fraction than to aerosol mass concentration, which suggests that most of the high variability of the $\mathrm{CCN}$ number concentration is due to the variations of the chemical composition, while a smaller part of it can be attributed to variability of the aerosol properties such as shape of the size distribution and the total particle number concentration.

\subsection{CCN modelling study and the sensitivity of calculated $N_{\mathrm{CCN}}$ to assumed aerosol size- dependence composition}

A particle's ability to act as CCN depends on its size and chemical composition. In this study both particle numbersize distribution and chemical bulk composition data are available. As such, supposing internal mixture of the species provided by ACSM and a simplified Köhler theory, we determine the critical supersaturation a dry diameter needs to be submitted to in order to be activated. Köhler's theory (Köh- ler, 1936) describes the equilibrium saturation ratio, $S$, over an aqueous solution droplet. According to Köhler's theory $S$ is defined by the ratio of $p$, the partial vapour pressure, and $p_{0}$, the saturation vapour pressure of water, and can be written as

$S=a_{\mathrm{w}} \exp \left(\frac{4 \sigma M_{\mathrm{w}}}{R T \rho_{\mathrm{w}} D_{\mathrm{drop}}}\right)$

where $a_{\mathrm{w}}$ is the water activity of the solution, $\rho_{\mathrm{w}}$ is the density of water, $M_{\mathrm{w}}$ is the molecular weight of water, $\sigma_{\mathrm{sol}}$ is the surface tension of the solution-air interface (considered constant and equal to the surface tension of water on this study, $0.072 \mathrm{~J} \mathrm{~m}^{-2}$ ), $R$ is the universal gas constant, $T$ is temperature, and $D_{\text {drop }}$ is the diameter of the droplet.

Following Petters and Kreidenweis (2007), we used a semi-empirical water activity parameterization for definition of $a_{\mathrm{w}}$ :

$a_{\mathrm{w}}=\left(1+\kappa \frac{D_{0}^{3}}{D_{\mathrm{drop}}^{3}-D_{0}^{3}}\right)^{-1}$,

where $\kappa$ is the hygroscopicity parameter, and $D_{0}$ the dry particle diameter. Substituting $a_{\mathrm{w}}$ in Eq. (1) with Eq. (2) 
provides the $\kappa$-Köhler equation:

$S=\left(1+\kappa \frac{D_{0}^{3}}{D_{\mathrm{drop}}^{3}-D_{0}^{3}}\right)^{-1} \exp \left(\frac{4 \sigma M_{\mathrm{w}}}{R T \rho_{\mathrm{w}} D_{\mathrm{drop}}}\right)$.

The $\mathrm{SS}_{\text {crit }}$ of a particle with properties $\left(D_{0}, \kappa\right)$ corresponds to the maximum value of $S$ obtained with Eq. (3) considering $D_{\text {drop }}$ as the independent variable. The $\mathrm{SS}_{\text {crit }}$ of any dry diameter with known chemical composition can be determined by numerical iteration considering variation on $D_{\text {drop }}$ and determining the equivalent equilibrium saturation rate.

The time-resolved mass fractions defined above can be used to feed the equation for $\kappa=f_{\text {org }} \kappa_{\text {org }}+f_{\text {inor }} \kappa_{\text {inor }}$ (Dusek et al., 2010; Rose et al., 2011) to get the ACSM/MAAPderived $\kappa$ as a function of time, where we use $\kappa_{\text {org }}=0.1$, and $\kappa_{\text {inor }}=0.7$ (Dusek et al., 2010). The mean ACSM/MAAPderived $\kappa$ value for the period studied was $0.15 \pm 0.04$, from this value $0.10 \pm 0.03$ can be attributed to the inorganic fraction, which implies that the largest variation experienced by $\kappa$ is due to the variation of the inorganic fraction. This value is lower than the global mean $\kappa$ values for continental regions $(0.27 \pm 0.21)$ and much lower than those value for marine regions (0.72 \pm 0.24$)$ (Andreae and Rosenfeld, 2008; Pringle et al., 2010). This is a result of the relatively low inorganic mass fraction. The mean $\kappa$ values present their lowest values around noon and their highest values after sunset.

\subsubsection{Internal mixture and ACSM chemical composition}

In this section we evaluate the relation of simulated and measured $N_{\mathrm{CCN}}$. We assume internal mixture of aerosol chemical composition derived from the ACSM, and use the aerosol size distribution determined by the DMPS to determine the $N_{\mathrm{CCN}}$ at a given supersaturation.

Initially, the size-independent hygroscopicity value, $\kappa_{\mathrm{si}}$, is determined using the values of Dusek et al. (2010) $(\kappa=0.1$ for organics and $\kappa=0.7$ for inorganics, $\kappa$ is considered zero for $\mathrm{BC})$. We then calculate the critical supersaturation for each diameter in the DMPS using Eq. (3) and $\kappa_{\mathrm{si}}$. The total modelled CCN concentration for a given supersaturation is determined integrating the DMPS-derived particle number-size distribution considering those classes of diameters whose critical supersaturation are lower or equal to the supersaturation under consideration. Since we have only 22 size channels for the whole size distribution it is necessary to interpolate them in order to be able to integrate them properly.

The modelled results indicate an overestimation of $N_{\mathrm{CCN}}$, with an increasing overestimation factor with supersaturation. A linear regression is applied for each group of comparisons, and indicates that the slope of the fitted line increases from 1.52 to 1.89 when going from 0.23 to $1.13 \%$ of supersaturation (Table $3 \mathrm{a}$ ), while the correlation coefficients $\left(R^{2}\right)$ tend to go from 0.44 to 0.79 , showing that the
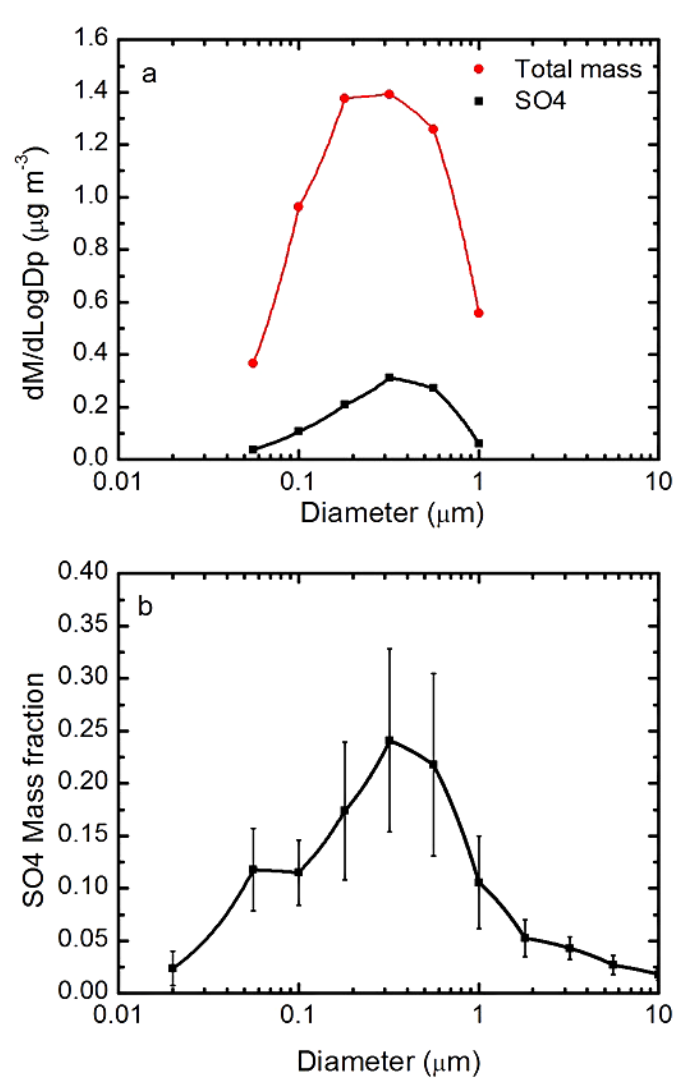

Figure 5. Comparison of modelled and measured CCN concentrations using internal mixing for the five estimated supersaturations $(0.23,0.45,0.68,0.90$, and $1.13 \%)$.

data scattering tends to decrease as the supersaturation increases and the overestimation tends to be higher as the particle size decreases. The mean relation between simulated and observed $N_{\mathrm{CCN}}$ was $1.44 \pm 0.48$ for $0.23 \%$ supersaturation and $1.91 \pm 0.40$ for $1.13 \%$ supersaturation. A lower error at lower supersaturation can be expected due to the larger importance of particle size regarding particle chemical composition when one considers larger sizes, as expected. Overall, the impact of chemical composition on calculated $N_{\mathrm{CCN}}$ decreases with decreasing supersaturation, partially because using bulk composition introduces less bias for larger sizes at lower supersaturations, and also by the fact that aerosol mass determined by the ACSM is mostly defined by the largest particles. In this case, the fraction of inorganic and organic mass in larger particles approach that measured by ACSM.

It can also be shown that if a smaller solubility factor $(\kappa \sim 0.60)$ is taken into account for the inorganic fraction, the modelled overestimation values are only slightly smaller (less than $5 \%$ ) than those shown in Table $3 \mathrm{a}$.

Considering the assumptions of size-averaged chemical composition, particles smaller than $40 \mathrm{~nm}$ do not affect the calculated CCN number concentration because $D_{0 \text {,crit }}$ at the $1.0 \%$ supersaturation was always above $40 \mathrm{~nm}$. 
Table 3. (a) Details of the predicted vs. measured $N_{\mathrm{CCN}}$ considering chemical composition measured by ACSM. $a$ is the slope of the fitted line using a linear regression, $R^{2}$ is the square of the correlation coefficient. (b) Details of the predicted vs. measured $N_{\text {CCN }}$ considering mean chemical-size dependency furnished by MOUDI + PIXE and ACSM hourly chemical composition.

\begin{tabular}{cccc}
\hline Supersaturation (\%) & $a[-]$ & $R^{2}[-]$ & $\begin{array}{c}\text { Mean predicted/measured } \\
N_{\mathrm{CCN}}( \pm \text { standard deviation })\end{array}$ \\
\hline (a) & & & \\
\hline 0.23 & 1.52 & 0.44 & $1.44 \pm 0.47$ \\
0.45 & 1.47 & 0.73 & $1.47 \pm 0.35$ \\
0.68 & 1.58 & 0.78 & $1.59 \pm 0.34$ \\
0.90 & 1.65 & 0.80 & $1.66 \pm 0.34$ \\
1.13 & 1.89 & 0.79 & $1.91 \pm 0.40$ \\
\hline (b) & & & \\
\hline 0.23 & 1.22 & 0.43 & $1.14 \pm 0.36$ \\
0.45 & 1.00 & 0.69 & $1.02 \pm 0.25$ \\
0.68 & 1.03 & 0.76 & $1.03 \pm 0.23$ \\
0.90 & 1.04 & 0.79 & $1.04 \pm 0.22$ \\
1.13 & 1.03 & 0.79 & $1.03 \pm 0.22$ \\
\hline
\end{tabular}
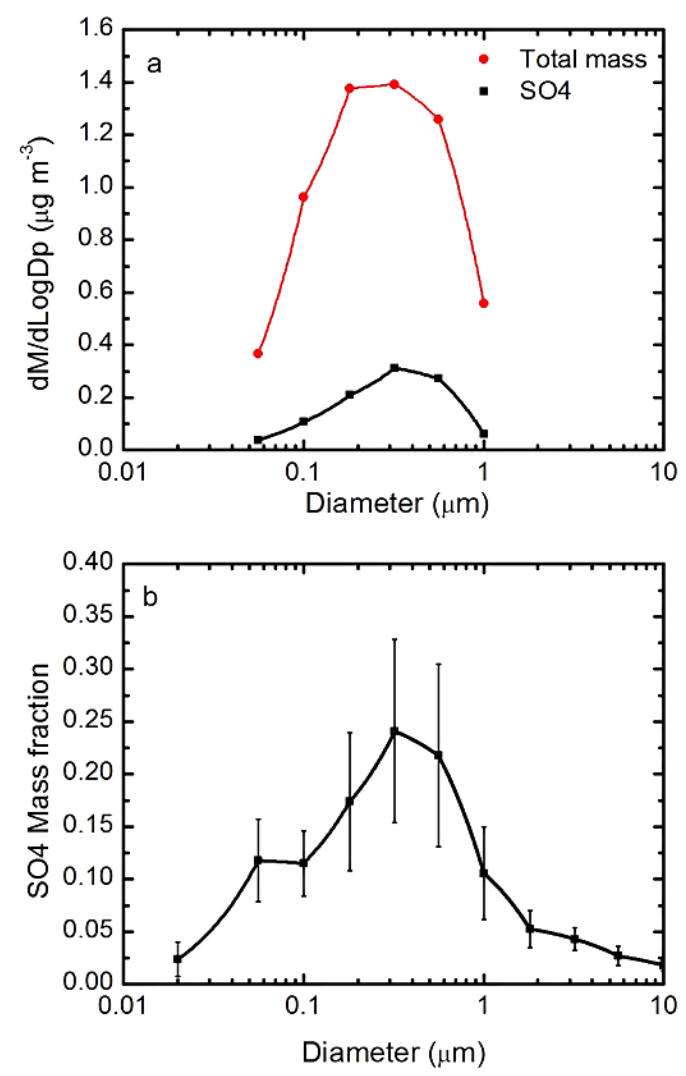

Figure 6. Mean value of (a) $d \mathrm{M} / d \log \mathrm{d}\left(\mu \mathrm{g} \mathrm{m}^{-3}\right)$ for the period of 15 August to 5 September 2012 and (b) $\mathrm{SO}_{4}$ mass fraction for the same period. The mass distribution was obtained using MOUDI samples, while the chemical composition was obtained after PIXE analysis. See text for more details.
A series of new simulations were performed varying the values of $\kappa_{\text {org }}$ from 0.1 to 0.0 , still considering internal mixing. The resulting overestimation becomes lower and lower as long as $\kappa_{\text {org }}$ decreases from 0.1 to 0.0 . The slope of fitted lines decreased to 1.27 and 1.52 for $0.23 \%$ and $1.13 \%$ supersaturation, respectively, when $\kappa_{\text {org }}$ is set to 0 . There is also a decrease on the mean ratio between modelled and observed $N_{\mathrm{CCN}}$. Values decreased to $1.21 \pm 0.42$ and $1.54 \pm 0.33$ for $0.23 \%$ and $1.13 \%$ supersaturation, respectively.

\subsubsection{Internal mixture and size-dependent chemical composition}

Also as part of NUANCE-SP project, a measurement campaign was performed from 15 August to 5 September 2012, at the roof of the Institute of Astronomy, Geophysics and Atmospheric Science (IAG), to chemically characterize aerosols from the SPMA. The building is about $150 \mathrm{~m}$ from the place where the $\mathrm{CCN}$ and aerosol measurements described above occurred. During this measurement campaign, aerosols were collected using a Micro-Orifice Uniform Deposit Impactor (MOUDI, model 100, MSP Corporation; Marple et al., 1986) once a day. The mass concentrations of the MOUDI samples were obtained gravimetrically using an electronic high-precision microbalance with a sensitivity of $1 \mu \mathrm{g}$ (Mettler-Toledo). Further analysis was performed using particle-induced X-ray emission (PIXE) and, more recently, ion chromatography, as described in Albuquerque et al. (2012), Vasconcellos et al. (2011) and Sánchez-Ccoyllo and Andrade (2002).

Figure 6a illustrates the $24 \mathrm{~h}$ mean mass distribution observed for the period. It is shown that most of the mass distribution is observed between 180 and $320 \mathrm{~nm}$. Considering the four stages from 100 to $560 \mathrm{~nm}$, the mean mass concentration sampled during the period of MOUDI operation was $10.9 \pm 6.3 \mu \mathrm{g} \mathrm{m}^{-3}$, which was comparable to the one evaluated by the ACSM and MAAP described above $\left(8.9 \pm 6.0 \mu \mathrm{g} \mathrm{m}^{-3}\right)$. Values are in good agreement with the previous works (Albuquerque et al., 2012; Vasconcellos et al., 2011; and Sánchez-Ccoyllo and Andrade, 2002) that have shown a size dependency of inorganic concentration matter in São Paulo. The work of Vasconcellos et al. (2011), for example, has shown that sulfate, nitrate, ammonium, calcium and sodium are the most abundant water-soluble ions in São Paulo. The analysis from 15 August to 5 September 2012 clearly shows that sulfate is a major component of the accumulation mode (diameters larger than $180 \mathrm{~nm}$ ), as is also shown in Fig. 6a, but values are largely variable. At $100 \mathrm{~nm}$ the fraction of sulfate (Fig. 6b) varied from 5.8 to $17.4 \%$, which decreased the critical supersaturation of particles with this size (from 0.5 to $0.3 \%$ considering only the contribution of $\left.\left(\mathrm{NH}_{4}\right)_{2} \mathrm{SO}_{4}\right)$.

For diameters smaller than $100 \mathrm{~nm}$ the fraction of sulfate decreases systematically, and one observes a value of about $2.5 \%$ at $20 \mathrm{~nm}$. On some occasions, nevertheless, an increase 
in sulfate fraction was seen at $50 \mathrm{~nm}$, which produced a relatively large mean value for that size. Considering only the contribution of $\left(\mathrm{NH}_{4}\right)_{2} \mathrm{SO}_{4}$, the variation of the critical supersaturation for particles of this size range would be from $0.7\left(\sim 7 \%\right.$ of $\left.\left(\mathrm{NH}_{4}\right)_{2} \mathrm{SO}_{4}\right)$ to $1.2 \%\left(\sim 23 \%\right.$ of $\left.\left(\mathrm{NH}_{4}\right)_{2} \mathrm{SO}_{4}\right)$, which suggests that particles around $50 \mathrm{~nm}$ are the lower limit size range for activation in this study.

Considering the large fraction of sulfate in the accumulation mode and the large fraction of organic compounds in total aerosol mass, one can argue that organic compounds predominate in smaller particles. One can also conclude that particles in the nucleation or Aitken size range were composed mostly of organics.

By observing the mass size distribution of the inorganic species, it is possible to improve the $N_{\mathrm{CCN}}$ modelling. Considering that mass distribution observed by MOUDI was shown to be consistent with aerosol mass spectrometer (AMS) data (Zhang et al., 2005), we assume that the inorganic size fraction during the $\mathrm{CCN}$ measurement period takes the same mean size dependency as observed for sulfate during measurements taken from 15 August to 5 September 2012. It is worth noting that the CCN closure utilizing AMS measurements tends to be more successful (typically within $20-50 \%)$, due to its fast time resolution $(1 \mathrm{~Hz})$ and ability to resolve size-dependent compositions. $\mathrm{CCN}$ closures in remote environments that use filter-based methods have nevertheless given good closure, on the order of a few percent (Bougiatioti et al., 2009, 2011).

The time-resolved mass fractions defined above can be used to feed the equation for $\kappa$ considering a variation with size as a function of time. For this propose we distributed the total inorganic mass from ACSM at a given time through all sizes using a polynomial function fitted through the points that represent the size-resolved sulfate mass fraction (Fig. 6b) and also ensure mass conservation.

Strictly, the polynomial function defined above can only be applied from 75 to $650 \mathrm{~nm}$. However, the application to particles with diameters smaller than $75 \mathrm{~nm}$ does not add large errors to the procedure, since usually there is only a small amount of mass below this size range. For particles larger than about $250 \mathrm{~nm}$, the procedure does not significantly modify the critical supersaturation, once at this diameter range the size is more important than chemical composition.

The new modelled results are presented in Fig. 7. The results of the size-dependent simulations are shown in Table $3 b$. Results show that when we use the inorganic fraction furnished by a MOUDI + PIXE analysis there is a reduction on the slope of fitted lines for the comparison of modelled and observed $N_{\mathrm{CCN}}$ for all supersaturations. For $0.23 \%$ supersaturation, for example, the slope is 1.22 , with $R^{2}=0.43$, which indicates a better agreement than when the mean values furnished by ACSM are considered for the simulation. A reduction on the mean relation between modelled and observed CCN, given now by $1.14 \pm 0.39$, is also observed . There is a reduction of the slope for all fitted lines relating
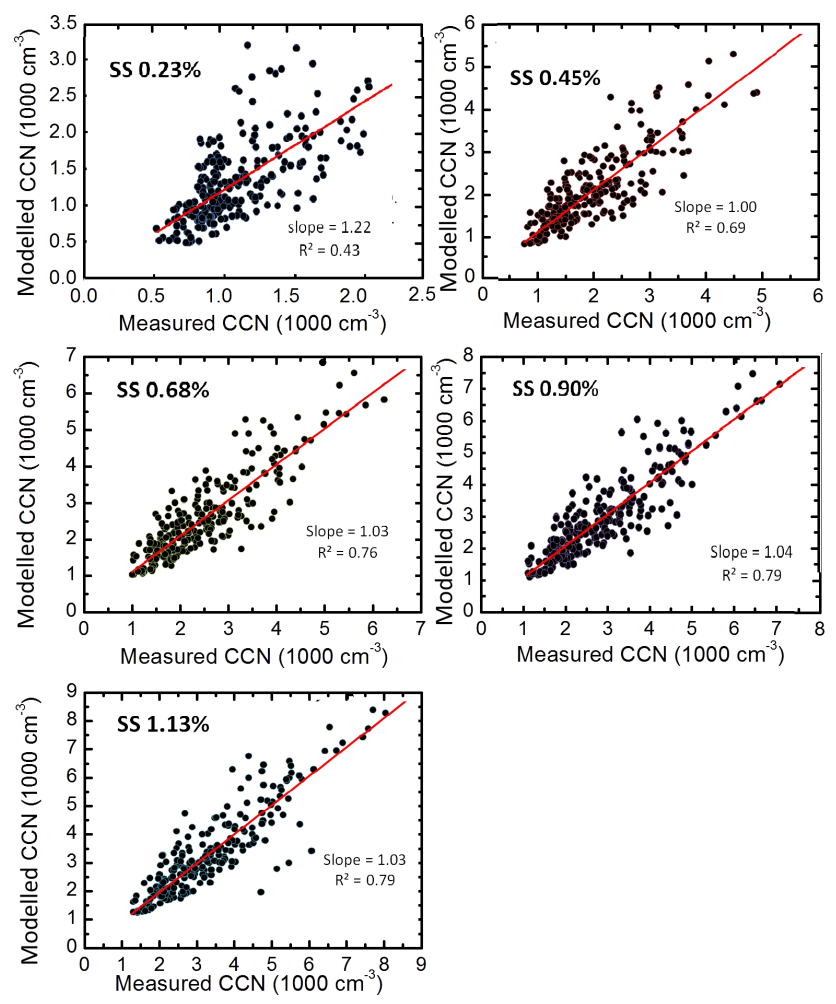

Figure 7. Comparison of modeled and measured CCN concentrations using internal mixing for the 5 estimated supersaturation using the inorganic size dependence based on MOUDI+PIXE analysis.

simulated and observed $N_{\mathrm{CCN}}$. For the case of $1.13 \%$ supersaturation, the slope of the fitted line is 1.03 with $R^{2}=0.79$, with mean relation between modelled and observed CCN of $1.04 \pm 0.22$. For this particular assumption, $D_{0, \text { crit }}$ at $1.13 \%$ supersaturation was, most of the time, above $65 \mathrm{~nm}$, with a mean value of $68 \mathrm{~nm}$.

Considering any $k_{\text {org }}$ different from 0.0 implies increasing the overestimation of $N_{\mathrm{CCN}}$ for all supersaturations. The overestimation, obviously, increases systematically for increasing supersaturation.

These results shows that the measured number distribution of the DMPS, combined with the chemical composition information provided by the ACSM and the mean chemical fraction information of the MOUDI + PIXE analysis, provides a reliable estimate of $\mathrm{CCN}$ concentration.

\subsubsection{Further improvement on the estimation of $N_{\mathrm{CCN}}$}

As previously stated, $\mathrm{CCN}$ closure utilizing AMS measurements tends to be more successful due to its fast time resolution and ability to resolve size-dependent composition. The use of mean values of MOUDI data, however, can significantly improve the estimation of $N_{\mathrm{CCN}}$, induce systematic bias as a function of the time of day for all supersaturations. The results are shown in Fig. 8, where we can see the mean relation between modelled and measured $N_{\mathrm{CCN}}$ as 


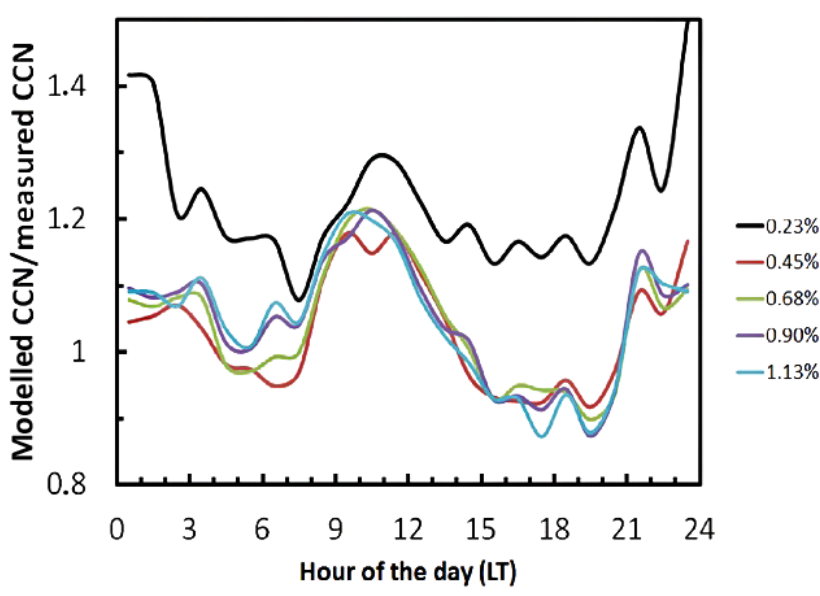

Figure 8. Mean value of modelled $N_{\mathrm{CCN}} /$ observed $N_{\mathrm{CCN}}$ for different supersaturations as a function of local time.

a function of the time of day. From 7 to $12 \mathrm{~h} \mathrm{LT}$, for example, the modelled $N_{\mathrm{CCN}}$ clearly overestimates observations, while an opposing tendency occurs during the afternoon. It can be concluded that the mean mass partition presented by the MOUDI analysis underestimates the soluble fraction during the morning and overestimates it during the afternoon. Castanho and Artaxo (2001) found that $40 \%$ of fine particles were explained by organic carbon (OC) and Ynoue and Andrade (2004) found for data collected in 1999 that OC explained $25 \%$ (during the day) and $43 \%$ (at night) of fine particles. Considering that previous analyses have shown that the inorganic fraction tends to be higher during the day than during the evening in São Paulo, it is likely that only a higherresolution $(\sim 6 \mathrm{~h})$ MOUDI analysis would allow studying and parameterizing the aerosol soluble fraction as a function of size and time of day.

\section{Conclusions}

Aerosol measurements in São Paulo city showed that the urban area is a strong source of aerosol particles. These particles can act as CCN and show large variability. Minimum and maximum observed $\mathrm{CCN}$ number concentrations at a given SS differed by a factor of 4-1 and suggest that chemical composition is the main factor controlling the fraction of aerosols that can act as $\mathrm{CCN}$.

The hygroscopicity range was substantially lower than that proposed for continental sites (Andreae and Rosenfeld, 2008), likely due to the higher mass fraction of organics. It was also observed that traffic emissions modulate the concentration of aerosols, the organic fraction and $\mathrm{CCN}$ efficiency.

The impact of $k_{\text {org }}$ on the calculated $N_{\mathrm{CCN}}$ concentration was examined calculating $N_{\mathrm{CCN}}$ for different $k_{\text {Org }}$ values $(0.1,0.07,0.05,0.03$ and 0.00$)$. Particle hygroscopicity was computed from the bulk composition (i.e. derived from
ACSM measurements) using Eq. (3). Based on the particle hygroscopicity and $k$-Kohler theory, the critical supersaturation was derived for each particle dry diameter $\left(D_{0}\right)$. The $N_{\mathrm{CCN}}$ at the five supersaturations were then computed from $D_{0}$ and the measured dry-particle-size distributions. Results suggest that taking the organic fraction into account in the particles' hygroscopicities only increases the overestimation of the modelled $N_{\mathrm{CCN}}$ regarding observations.

Results show an increase in aerosol hygroscopicity in the afternoon as a result of aerosol photochemical processing, leading to an enhancement of both organic and inorganic secondary aerosols in the atmosphere, as well as an increase in aerosol average diameter.

Our study suggests that the prediction of $N_{\mathrm{CCN}}$ can be achieved with an error of about $\pm 24 \%$ considering a mean size-dependent soluble fraction based on MOUDI+PIXE analysis. The knowledge of the soluble salt fraction is sufficient for description of CCN activity at São Paulo, which is consistent with other closure studies conducted in the past.

The results from these measurements can be used to constrain the uncertainty associated with assumptions in GCM (global circulation model) modelling studies of the aerosol indirect effect. As suggested in a recent study (Sotiropoulou et al., 2007), if the CCN prediction error is on the order of $20 \%$, it may not contribute a significant source of error in the assessment of the aerosol indirect effect.

Acknowledgements. This research was funded by the FAPESP (São Paulo Science Foundation).

Edited by: J. Allan

\section{References}

Albuquerque, T. T, Andrade, M. F., and Ynoue, R. Y.: Characterization of atmospheric aerosols in the city of São Paulo, Brazil: comparisons between polluted and unpolluted periods, Environ. Monit. Assess., 184, 969-984, doi:10.1007/s10661-011-2013-y, 2012.

Allan, J. D., Delia, A. E., Coe, H., Bower, K. N., Alfarra, M. R., Jimenez, J. L., Middlebrook, A. M., Drewnick, F., Onasch,T. B., Canagaratna, M. R., Jayne, J. T., and Worsnop D. R: A generalised method for the extraction of chemically resolved mass spectra from Aerodyne aerosol mass spectrometer data, J. Aerosol Sci., 35, 909-922, doi:10.1016/j.jaerosci.2004.02.007, 2004.

Andreae, M. O. and Rosenfeld, D.: Aerosol-cloud-precipitation interactions. Part 1. The nature and sources of cloud-active aerosols, Earth Sci. Rev., 89, 13-41, 2008.

Bigg, E. K.: Discrepancy between observation and prediction of concentrations of cloud condensation nuclei, Atmos. Res., 20, 82-86, 1986.

Bougiatioti, A., Fountoukis, C., Kalivitis, N., Pandis, S. N., Nenes, A., and Mihalopoulos, N.: Cloud condensation nuclei measurements in the marine boundary layer of the Eastern Mediter- 
ranean: CCN closure and droplet growth kinetics, Atmos. Chem. Phys., 9, 7053-7066, doi:10.5194/acp-9-7053-2009, 2009.

Bougiatioti, A., Nenes, A., Fountoukis, C., Kalivitis, N., Pandis, S. N., and Mihalopoulos, N.: Size-resolved CCN distributions and activation kinetics of aged continental and marine aerosol, Atmos. Chem. Phys., 11, 8791-8808, doi:10.5194/acp-11-87912011, 2011.

Broekhuizen, K., Chang, R.Y.-W., Leaitch, W. R., Li, S.-M., and Abbatt, J. P. D.: Closure between measured and modeled cloud condensation nuclei $(\mathrm{CCN})$ using size-resolved aerosol compositions in downtown Toronto, Atmos. Chem. Phys., 6, 2513-2524, doi:10.5194/acp-6-2513-2006, 2006.

Cantrell, W., Shaw, G., Cass, G. R., Chowdhury, Z., Prather, K. A., Hughes, L. S., Prather, K. A., Guazzotti, S. A., and Coffee, K. R.: Closure between aerosol particles and cloud condensation nuclei at Kaashidhoo Climate Observatory, J. Geophys. Res., 106, 28711-28718, 2001.

Castanho, A. and Artaxo, P.: Wintertime and summertime São Paulo aerosol source apportionment study, Atmos. Environ., 35, 48894902, 2001.

CETESB - Companhia de Tecnologia de Saneamento Ambiental. Relatório Anual de Qualidade do Ar no Estado de São Paulo 2006, São Paulo, 2007.

Chang, R. Y. W., Liu, P. S. K., Leaitch, W. R., and Abbatt, J. P. D.: Comparison between measured and predicted CCN concentrations at Egbert, Ontario: Focus on the organic aerosol fraction at a semi-rural site, Atmos. Environ., 41, 8172-8182, 2007.

Conant, W. C., VanReken, T. M., Rissman, T. A., Varutbangkul, V., Jonsson, H. H., Nenes, A., Jimenez, J. L., Delia, A. E., Bahreini, R., Roberts, G. C., Flagan, R. C., and Seinfeld, J. H.: AerosolCloud Drop Concentration Closure in Warm Cumulus. J. Geophys. Res., 109, D13204, doi:10.1029/2003JD004324, 2004

Dusek, U., Frank, G. P., Curtius, J., Drewnick, F., Schneider, J., Kürten, A., Rose, D., Andreae, M. O., Borrmann, S., and Pöschl, U.: Enhanced organic mass fraction and decreased hygroscopicity of cloud condensation nuclei (CCN) during new particle formation events, Geophys. Res. Lett., 37, L03804, doi:10.1029/2009GL040930, 2010.

Ervens, B., Cubison, M., Andrews, E., Feingold, G., Ogren, J. A., Jimenez, J. L. , DeCarlo, P., and Nenes, A.: Prediction of cloud condensation nucleus number concentration using measurements of aerosol size distributions and composition and light scattering enhancement due to humidity, J. Geophys. Res., 112, D10S32, doi:10.1029/2006JD007426, 2007.

Gasparini, R., Li, R., Collins, D. R., Ferrare, R. A., and Brackett, V. G.: Application of aerosol hygroscopicity measured at the Atmospheric Radiation Measurement Program's Southern Great Plains site to examine composition and evolution, J. Geophys. Res., 111, D05S12, doi:10.1029/2004JD005448, 2006.

Gunthe, S. S., King, S. M., Rose, D., Chen, Q., Roldin, P., Farmer, D. K., Jimenez, J. L., Artaxo, P., Andreae, M. O., Martin, S. T., and Pöschl, U.: Cloud condensation nuclei in pristine tropical rainforest air of Amazonia: size-resolved measurements and modeling of atmospheric aerosol composition and CCN activity, Atmos. Chem. Phys., 9, 7551-7575, doi:10.5194/acp-9-75512009, 2009.

Gunthe, S. S., Rose, D., Su, H., Garland, R. M., Achtert, P., Nowak, A., Wiedensohler, A., Kuwata, M., Takegawa, N., Kondo, Y., Hu, M., Shao, M., Zhu, T., Andreae, M. O., and Pöschl, U.: Cloud condensation nuclei $(\mathrm{CCN})$ from fresh and aged air pollution in the megacity region of Beijing, Atmos. Chem. Phys., 11, 1102311039, doi:10.5194/acp-11-11023-2011, 2011. 15721, 15723

Gurjar, B., Butler, T., Lawrence, M., and Lelieveld, J.: Evaluation of emissions and air quality in megacities, Atmos. Environ., 42, 1593-1606, doi:10.1016/j.atmosenv.2007.10.048, 2008.

Hänel, G.: Radiation budget of the boundary layer: Part II. Simultaneous measurement of mean solar volume absorption and extinction coefficients of particles, Beitr. Phys. Atmos., 60, 241-247, 1987.

Köhler, H.: The nucleus in and the growth of hygroscopic droplets, Trans. Faraday Soc., 32, 1152-1161, 1936.

Kuhn, U., Ganzeveld, L., Thielmann, A., Dindorf, T., Schebeske, G., Welling, M., Sciare, J., Roberts, G., Meixner, F. X., Kesselmeier, J., Lelieveld, J., Kolle, O., Ciccioli, P., Lloyd, J., Trentmann, J., Artaxo, P., and Andreae, M. O.: Impact of Manaus City on the Amazon Green Ocean atmosphere: ozone production, precursor sensitivity and aerosol load, Atmos. Chem. Phys., 10, 9251-9282, doi:10.5194/acp-10-9251-2010, 2010.

Kuwata, M., Kondo, Y., and Takegawa, N.: Critical condensed mass for activation of black carbon as cloud condensation nuclei in Tokyo, J. Geophys. Res., 114, D20202, doi:10.1029/2009JD012086, 2009.

Kuwata, M., Kondo, Y., Miyazaki, Y., Komazaki, Y., Kim, J. H., Yum, S. S., Tanimoto, H., and Matsueda, H.: Cloud condensation nuclei activity at Jeju Island, Korea in spring 2005, Atmos. Chem. Phys., 8, 2933-2948, doi:10.5194/acp-8-2933-2008, 2008.

Kuwata, M., Kondo, Y., Mochida, M., Takegawa, N., and Kawamura, K.: Dependence of CCN activity of less volatile particles on the amount of coating observed in Tokyo, J. Geophys. Res., 112, D11207, doi:10.1029/2006JD007758, 2007.

Lance, S., Raatikainen, T., Onasch, T., Worsnop, D. R., Yu, X.-Y., Alexander, M. L., Stolzenburg, M. R., McMurry, P. H., Smith, J. N., and Nenes, A.: Aerosol mixing-state, hygroscopic growth and cloud activation efficiency during MIRAGE 2006, Atmos. Chem. Phys., 13, 5049-5062, doi:10.5194/acp-13-5049-2013, 2013.

Liu, P. S. K., Leaitch, W. R., Banic, C. M. , Li, S.-M., Ngo, D., and Megaw, W. J.: Aerosol observations at Chebogue Point during the 1993 North Atlantic Regional Experiment: Relationships among cloud condensation nuclei, size distribution, and chemistry, J. Geophys. Res., 101, 28971-28990, doi:10.1029/96JD00445, 1996.

Marple, V. A., Rubow, K. L., Ananth, G. P., and Fissan, H. J.: Microorifice uniform impactor, J. Aerosol Sci., 17, 489-494, 1986.

Martin, G. M., Johnson, D. W., and Spice, A.: The measurement and parameterization of effective radius of droplets in warm stratocumulus clouds, J. Atmos. Sci., 51, 1823-1842, 1994.

Matsumoto, K., Tanaka, H., Nagao, I., and Ishizaka, Y.: Contribution of particulate sulfate and organic carbon to cloud condensation nuclei in the marine atmosphere, Geophys. Res. Lett., 24, 655-658, 1997.

McFiggans, G., Artaxo, P., Baltensperger, U., Coe, H., Facchini, M. C., Feingold, G., Fuzzi, S., Gysel, M., Laaksonen, A., Lohmann, U., Mentel, T. F., Murphy, D. M., O’Dowd, C. D., Snider, J. R., and Weingartner, E.: The effect of physical and chemical aerosol properties on warm cloud droplet activation, Atmos. Chem. Phys., 6, 2593-2649, doi:10.5194/acp-6-2593-2006, 2006. 
Mei, F., Setyan, A., Zhang, Q., and Wang, J.: CCN activity of organic aerosols observed downwind of urban emissions during CARES, Atmos. Chem. Phys., 13, 12155-12169, doi:10.5194/acp-13-12155-2013, 2013.

Middlebrook, A. M., Bahreini, R., Jimenez, J. L., and Canagaratna, M. R.: Evaluation of composition dependent Collection Efficiencies for the Aerodyne Aerosol Mass Spectrometer Using Field Data, Aerosol Sci. Technol., 46, 258-271, 2012.

Müller, T., Henzing, J. S., de Leeuw, G., Wiedensohler, A., Alastuey, A., Angelov, H., Bizjak, M., Collaud Coen, M., Engström, J. E., Gruening, C., Hillamo, R., Hoffer, A., Imre, K., Ivanow, P., Jennings, G., Sun, J. Y., Kalivitis, N., Karlsson, H., Komppula, M., Laj, P., Li, S.-M., Lunder, C., Marinoni, A., Martins dos Santos, S., Moerman, M., Nowak, A., Ogren, J. A., Petzold, A., Pichon, J. M., Rodriquez, S., Sharma, S., Sheridan, P. J., Teinila, K., Tuch, T., Viana, M., Virkkula, A., Weingartner, E., Wilhelm, R., and Wang, Y. Q.: Characterization and intercomparison of aerosol absorption photometers: result of two intercomparison workshops, Atmos. Meas. Tech., 4, 245-268, doi:10.5194/amt-4-245-2011, 2011.

Ng, N. L., Herndon, S. C., Trimborn, A., Canagaratna, M. R., Croteau, P. L., Onasch, T. B., Sueper, D., Worsnop, D. R., Zhang, Q., Sun, Y. L., and Jayne, J. T.: An Aerosol Chemical Speciation Monitor (ACSM) for Routine Monitoring of the Composition and Mass Concentrations of Ambient Aerosol, Aerosol Sci. Technol., 45, 780-794, doi:10.1080/02786826.2011.560211, 2011.

Padró, L. T., Moore, R. H., Zhang, X., Rastogi, N., Weber, R. J., and Nenes, A.: Mixing state and compositional effects on CCN activity and droplet growth kinetics of size-resolved $\mathrm{CCN}$ in an urban environment, Atmos. Chem. Phys., 12, 10239-10255, doi:10.5194/acp-12-10239-2012, 2012.

Petters, M. D. and Kreidenweis, S. M.: A single parameter representation of hygroscopic growth and cloud condensation nucleus activity, Atmos. Chem. Phys., 7, 1961-1971, doi:10.5194/acp-71961-2007, 2007.

Petzold, A. and Schönlinner, M.: Multi-angle absorption photometry - a new method for the measurement of aerosol light absorption and atmospheric black carbon, J. Aerosol Sci., 35, 421-441, 2004

Petzold, A., Schloesser, M., Sheridan, P. J., Arnott, W. P., Ogren, J. A., and Virkkula, A.: Evaluation of multi-angle absorption photometry for measuring aerosol light absorption, Aerosol Sci. Technol., 39, 40-51, 2005.

Pringle, K. J., Tost, H., Pozzer, A., Pöschl, U., and Lelieveld, J.: Global distribution of the effective aerosol hygroscopicity parameter for CCN activation, Atmos. Chem. Phys., 10, 52415255, doi:10.5194/acp-10-5241-2010, 2010.

Quinn, P. K., Covert, D. S., Bates, T. S., Kapustin, V. N., RamseyBell, D. C., and McInnes, L. M.: Dimethylsulfide/cloud condensation nuclei/climate system: relevant size-resolved measurements of the chemical and physical properties of atmospheric aerosol particles, J. Geophys. Res., 98, 10411-10427, 1993.

Quinn, P. K., Bates, T. S., Coffman, D., Onasch, T. B., Worsnop, D., Baynard, T., de Gouw, J. A., Goldan, P. D., Kuster, W. C., Williams, E., Roberts, J. M., Lerner,B., Stohl, A., Pettersson, A., and Lovejoy, E. R.: Impacts of sources and aging on submicrometer aerosol properties in the marine boundary layer across the Gulf of Maine, J. Geophys. Res., 111, D23S36, doi:10.1029/2006JD007582, 2006.

Rissler, J., Swietlicki, E., Zhou, J., Roberts, G., Andreae, M. O., Gatti, L. V., and Artaxo, P.: Physical properties of the submicrometer aerosol over the Amazon rain forest during the wet to-dry season transition - comparison of modeled and measured CCN concentrations, Atmos. Chem. Phys., 4, 2119-2143, doi:10.5194/acp-4-2119-2004, 2004.

Roberts, G. C., Artaxo, P., Zhou, J., E. Swietlicki, E., and Andreae, M. O.: Sensitivity of CCN spectra on chemical and physical properties of aerosol: A case study from the Amazon Basin, J. Geophys. Res., 107, 8070, doi:10.1029/2001JD000583, 2002.

Rose, D., Gunthe, S. S., Su, H., Garland, R. M., Yang, H., Berghof, M., Cheng, Y. F., Wehner, B., Achtert, P., Nowak, A., Wiedensohler, A., Takegawa, N., Kondo, Y., Hu, M., Zhang, Y., Andreae, M. O., and Pöschl, U.: Cloud condensation nuclei in polluted air and biomass burning smoke near the megacity Guangzhou, China - Part 2: Size-resolved aerosol chemical composition, diurnal cycles, and externally mixed weakly CCN-active soot particles, Atmos. Chem. Phys., 11, 2817-2836, doi:10.5194/acp-11-2817-2011, 2011.

Sánchez-Ccoyllo, O. R. and Andrade, M. F.: The influence of meteorological conditions on the behavior of pollutants concentrations in São Paulo, Brazil, Environ. Poll., 116, 257-263, 2002.

Shinozuka, Y., Clarke, A. D., DeCarlo, P. F., Jimenez, J. L., Dunlea, E. J., Roberts, G. C., Tomlinson, J. M., Collins, D. R., Howell, S. G., Kapustin, V. N., McNaughton, C. S., and Zhou, J.: Aerosol optical properties relevant to regional remote sensing of $\mathrm{CCN}$ activity and links to their organic mass fraction: airborne observations over Central Mexico and the US West Coast during MILAGRO/INTEX-B, Atmos. Chem. Phys., 9, 6727-6742, doi:10.5194/acp-9-6727-2009, 2009.

Sotiropoulou, R. E. P., Nenes, A., Adams, P. J., and Seinfeld, J. H.: Cloud condensation nuclei prediction error from application of Köhler theory, Importance for the aerosol indirect effect, J. Geophys. Res., 112, D12202, doi:10.1029/2006JD007834, 2007.

VanReken, T. M., Rissman, T. A., Roberts, G. C., Varutbangkul, V., Jonsson, H. H. , Flagan, R. C, and Seinfeld, J. H.: Toward aerosol/cloud condensation nuclei (CCN) closure during CRYSTAL-FACE, J. Geophys. Res., 108, 4633, doi:10.1029/2003JD003582, 2003

Vasconcellos, P. C., Souza, D. Z., Simone, G. A., Araújo, M. P., Naoto, E., Nascimento, K. H., Cavalcante, F. S., Santos, M., Smichowski, P., and Behrentz, E.: Comparative study of the atmospheric chemical composition of three South American cities, Atmos. Environ., 45, 5770-5777, 2011.

Wang, J., Lee, Y.-N., Daum, P. H., Jayne, J., and Alexander, M. L.: Effects of aerosol organics on cloud condensation nucleus (CCN) concentration and first indirect aerosol effect, Atmos. Chem. Phys., 8, 6325-6339, doi:10.5194/acp-8-6325-2008, 2008.

Wiedensohler, A., Cheng, Y. F., Nowak, A., Wehner, B., Achtert, P., Berghof, M., Birmili, W., Wu, Z. J., Hu, M., Zhu, T., Takegawa, N., Kita, K., Kondo, Y., Lou, S. R., Hofzumahaus, A., Holland, F., Wahner, A., Gunthe, S. S., Rose, D., Su, H., and Pöschl, U.: Rapid aerosol particle growth and increase of cloud condensation nucleus activity by secondary aerosol formation and condensation: A case study for regional air pollution in northeastern China, J. Geophys. Res., 114, D00G08, doi:10.1029/2008JD010884, 2009. 
Winklmayr, W., Reischl, G. P., Lindner, A. O., and Berner, A.: A new electromobility spectrometer for the measurement of aerosol size distributions in the size range from 1 to $1000 \mathrm{~nm}$, J. Aerosol Sci., 22, 289-296, 1991.

Ynoue, R. Y. and Andrade, M. F.: Size-Resolved Mass Balance of Aerosol Particles over the São Paulo Metropolitan Area of Brazil, Aerosol Sci. Technol., 38, 52-62, doi:10.1080/02786820490466756, 2004.

Yum, S. S., Hudson, J. G., Song, K. Y., and Choi, B.C.: Springtime cloud condensation nuclei concentrations on the west coast of Korea, Geophys. Res. Lett., 32, L09814, doi:10.1029/2005GL022641, 2005.
Yum, S. S., Roberts, G., Kim, J. H., Song, K. Y., and Kim, D. Y.: Submicron aerosol size distributions and cloud condensation nuclei concentrations measured at Gosan, Korea, during the Atmospheric brown clouds East Asian Regional Experiment 2005, J. Geophys. Res., 112, D22S32, doi:10.1029/2006JD008212, 2007.

Zhang, Q., Canagaratna, M. R., Jayne, J. T., Worsnop, D. R., and Jimenez, J.-L.: Time- and size-resolved chemical composition of submicron particles in Pittsburgh: Implications for aerosol sources and processes, J. Geophys. Res., 110, D07S09, doi:10.1029/2004JD004649, 2005. 